FILOLOGIJA 67, Zagreb 2016.

Gordana Čupković

UDK 821.163.42-6"18"

http://doi.org/10.21857/y26kecvvx9

Izvorni znanstveni članak

Primljen 17.I.2016.

Prihvaćen za tisak 27.VI.2016.

Sveučilište u Zadru

Odsjek za hrvatski jezik i književnost

Odjel za kroatistiku i slavistiku

Obala Kralja Petra Krešimira IV. 2, HR-23000 Zadar

gcupkov@unizd.hr

\title{
POLJIČKO-ŠIBENSKE ISPRAVE IZ 1801.
}

U radu se objavljuju dva ćirilična pisma poljičkoga kneza Matija Mijanovića šibenskim vlastima iz 1801., pronađena u Državnom arhivu u Šibeniku, te se daje njihova latinična transliteracija, usporedna analiza strukturnih obilježja, jezika, grafijskih i paleografskih osobitosti. Utvrđuju se tekstološke, sadržajne i jezične podudarnosti i razlike proučavanih tekstova te se upućuje na pojedine diskurzivne specifičnosti koje proizlaze iz slijeda pisama i pošiljateljeva promišljanja njihove recepcije.

\section{Kontekst isprava}

Dva originalna i javnosti do sad nepoznata dokumenta pronađena $u$ Državnom arhivu u Šibeniku (obilježena kao arhivski spis 471 i arhivski spis 978 ${ }^{1}$ ) čine ćirilične isprave (pisma) koja je poljički knez Matij Mijanović $^{2}$ u dva navrata, u ožujku i lipnju 1801. uputio vlastima Šibenika. Tim pismima, kao nadređeni posrednik, prenosi zahtjev predstavnika župnoga vijeća Crkve svetoga Martina iz poljičkoga sela Podstrane da se utječe na voditelje gradnje koji su se ugovorom obvezali sagraditi oltar crkve i za to dobili određena sredstva, ali ugovoreno nisu izvršili nego je jedan

\footnotetext{
${ }^{1}$ Spisi nisu katalogizirani i nemaju suvremenu signaturu, navedene brojke nalaze se uz arhivski opis dokumenta na talijanskom. U pronalaženju spisa pomogla mi je arhivistica Draženka Vlahov, kojoj ovom prigodom zahvaljujem. Zahvaljujem i ravnateljici Državnoga arhiva u Šibeniku, mr. sc. Marini Mučalo na susretljivosti prilikom dopuštanja objavljivanja digitalnih snimaka.

${ }^{2}$ Ime kneza navodim $\mathrm{u}$ izvornom obliku, onako kako je zapisano $\mathrm{u}$ ispravama. Uobičajeno se u literaturi to ime navodi standardizirano: Matija Mihanović.
} 
od njih otišao (pobjegao) u Šibenik. Knez stoga traži od šibenskih vlasti da spomenutog voditelja gradnje vrate tamo gdje je ugovor potpisan (u područje nadležnosti splitske vlasti) kako bi se izvršile potpisane obveze, ili, ukoliko ne namjerava poštivati ugovoreno, neka se zatraži od njega da vrati primljena sredstva. Pisma su pisana kurzivnom ćirilicom a priloženi su im i dodatci na drugom pismu (latinici) i drugom jeziku (talijanskom).

U Poljicima se od samog doseljavanja, zahvaljujući geografskom položaju i održavanoj političkoj autonomiji prožimaju civilizacijski utjecaji iz unutrašnjosti (iz Bosne) s onima koji dolaze s obale ${ }^{3}$ : poljičica je, kao i hrvatska ćirilica u cjelini (u slovopisu, grafiji i ortografiji) obilježena s jedne strane utjecajem glagoljice, a s druge utjecajem talijanskih grafijskih uzusa. Za razliku od glagoljice koja se funkcionalno vezala uz svečaniji, liturgijski stil ${ }^{4}$, poljičicom se pišu administrativni i privatni spisi sve do ustoličavanja francuske uprave i ukidanja poljičke autonomije (1807.) $)^{5}$.

Poljička Republika u prvim godinama 19. st. kao posebno područje pod austrijskom vlasti uživa određene aristokratske povlastice ${ }^{6}$. Knez Matij Mijanović spominje se u izaslanstvu Poljičana koji su 1799. u Zadru tražili vraćanje povlastica dokinutih ustavom iz 1798., posredno prijeteći i bunom koja bi mogla izbiti među narodom (Pivčević 1921:98) ${ }^{7}$. U

${ }^{3} » U$ Poljicima, razmjerno izoliranom dijelu Dalmacije, otvorenom još dublje prema unutrašnjosti, bosanična se tradicija - prema sačuvanim tekstovima - može pratiti od XV. st.«(Žagar 2009:211).

$4{ }_{» P u n i}$ i razvijeniji život poljičice, kao varijante bosančice (hrvatske ćirilice) nastupa u novovjekovlju, od XVI. st., kada supostoji s glagoljičnim knjigama (istočnoslaveniziranoga jezika) koje se koriste u liturgiji« (Žagar 2009:213).

${ }^{5}$ Sjemenište za izobrazbu glagoljaških svećenika u Prikom kod Omiša osnovao je splitski nadbiskup 1750. i djelovalo je sve do 1821. U tom »rasadištu « pismenosti na poljičici obrazovanje se temeljilo na trigrafičnosti: "glagoljica u liturgijskom čitanju, poljičica u pisanju i čitanju; latinica kao pismo zemljopisnoga i kulturnog okružja« (Žagar 2009:213). Radi »potreba dopisivanja i slanja okružnica brojnom glagoljaškom kleru, morala je i splitska nadbiskupska kancelarija imati posebnog pisara, `kančilira<, koji se s vikarom izvanjskim i pojedinim župnicima dopisivao hrvatskim jezikom, a pismom bosančicom. A to pismo su ne samo poznavali nego su se njime povremeno služili i poneki nadbiskupi i generalni vikari« (Zelić-Bućan 2000:15).

${ }^{6}$ Austrijska vlast umjesto općeg providura u Zadru uspostavlja carsku kraljevsku vladu dok su po drugim mjestima, koja su u doba mletačke vlasti imala knezove ili providure, uspostavljene »c. k. mjesne oblasti«, kakav je naziv dobio i poljički stol (kojeg su činili veliki knez i dvanaestorica malih knezova), u sudbenim i upravnim poslovima ovisne o vladi u Zadru. Poljičani nastavljaju plaćati danak i obvezuju se na sudjelovanje u vojnim akcijama zauzvrat tražeći potvrdu svojih starih povlastica, koje su im u određenoj mjeri ipak ukinute novim ustavom za Poljica iz 1798. (Pivčević 1921:97-98).

7 »da je poljički sto bio prisiljen izjaviti, da od sebe otklanja svaku odgovornost, ako bi ogorčeni puk, ne zadovoljivši mu se, prekoračio mjere i počinio javnih nasilja« 
ispravama se bilježi i njegov angažman oko zadržavanja plemićkih povlastica Poljičana iseljenih po dalmatinskim gradovima; 1799. vladi u Zadru dostavio je točan popis iseljenih plemića kako bi mogla vratiti privilegije ukinute zbog ranijih netočnih popisa (Pivčević 1921:100). Matij Mijanović prokaratur sudc ujedno je dva puta zabilježen među ovjeroviteljima isprave iz Gradca u Poljicima kojom se Poljičanima iseljenim u Zadar dopuštaju »prava i privilegije poljičkih knezova " (Brković 2005:262). U ispravama koje objavljuje Mišerda (2003) ime kneza Matija Mijanovića pojavljuje se u spisima raznih uredbi izravno: kao adresant ${ }^{8}$, potpisnik ${ }^{9}$, svjedok, ovjerovitelj ili sudionik pravnih čina ${ }^{10}$, ili neizravno: u dataciji ${ }^{11}$, kao sudionik minulog pravnog čina (s vremenske distance) ${ }^{12}$ te kao objekt pritužbe ${ }^{13}$.

\section{Struktura isprava}

U proučavanim ispravama knez Matij Mijanović jest adresant (u prvom licu jednine u prvom pismu, u prvom licu množine u drugom) i potpisnik koji posreduje traženja svojih podanika (oštećenika) iz Podstrane. Struktura dviju isprava ponešto je različita s obzirom na njihovu sadržajnu navezanost i vremenski tijek nastanka. Starija isprava (prvo pismo, $\mathrm{u}$ nastavku rada: T1) sadrži redom: inskripciju, salutaciju, ekspoziciju, dispoziciju te eshatokol s datacijom (mjesto i vrijeme) i potpisom adresan-

(Pivčević 1921:98).

${ }^{8}$ Sitno, 1802: mi MM knez veliki (Mišerda 2003:459); Sitno, 1802: veliki knez MM piše (2003:462) te potpis na praznom obrascu, Poljica, oko 1802. (2003:463).

${ }^{9}$ Mišerda (2003:191-192) navodi dva Regesta iz 1800. (potpisuju ih MM i kančiliri Matij Fladušić i Mijovija Vladušić).

10 Mišerda (2003:296) Karta od dila u Vilaru iz 1772. među djeliteljima zemljišta navodi i katunara od sela Sitnoga: $p$. knez Matij Mijanović; vojvoda Matij Mijanović zabilježen je kao ovjerovitelj oporuke (Sitno, 1790.; 2003:399-400); ovjerovitelj presude (Donji Dolac 1791.; 2003:400-401; Putišići, 1804.: knez od Sitnoga i prokaratur općine poljičke, 2003:404-407); adresant, svjedok i ovjerovitelj presude: Sitno, 1802. (2003:457-458); ovjerovitelj pozajmice (Poljica, 1799., veliki knez; 2003:444); potvrditelj setencije, 'presude' (1801.; Gornje Polje: plemeniti gon MM, knez veliki ove provincije (2003:451-452), svjedok i ovjerovitelj diobe: Dolac Gornji, 1802 (2003:459-461).

${ }^{11}$ Donji Dolac, 1796 - 1800: za knežije svitloga gna kneza velikoga (Mišerda 2003:432); Putišići, 1800: za kneza Matija...pisa Anton Pavić (2003:445); Trnbusi, 1800.: za kneza Mihanovića (2003:447); Sitno, 1800.: Mandat velikoga kneza Matija Mihanovića (2003:448449), isto: Poljica, 1801 (2003:453), isto: Dolac Gornji, 1802 (2003:461); za kneza Matija, Donji Dolac, 1803 (2003:467).

${ }^{12}$ Davatelj setencije u 3. licu: Poljica, 1804. (Mišerda, 2003:480); uredba: veliki knez MM odredio je, Donji Dolac 1802. (2003:462).

13 Kao predmet pritužbe njegovo ime pojavljuje se $\mathrm{u}$ jednoj ispravi: Srijane 1800/1801: Isti mi je knez Mijanović u sve pomanka besidi i nije mi naplatija kako je obeća (Mišerda 2003:450). 
ta ${ }^{14}$. Novija isprava (drugo pismo, u nastavku rada: T2) sadrži: inskripciju, ekspoziciju, dispoziciju i finalnu klauzulu te eshatokol. U obje su isprave identični inskripcija (carskom kraljevskom vladanju od Šibenika) i struktura eshatokola: mjesto (Poljica), datum te potpis adresanta (knez MM); ni u jednom od proučavanih pisama nije navedeno ime ili potpis pisara. Razlike u strukturi isprava proizlaze iz njihove uzročno-posljedične povezanosti: drugo pismo (T2) poslano je jer je prvo ostalo bez odgovora pa svojom strukturom osim što ponavlja traženje iz prvoga pisma odražava i reakciju na izostanak odgovora; slijedom toga u njemu izostaje konvencionalni pozdrav a dodana je osobita finalna klauzula kojom se naglašava zaštita prava trećih lica kao i njihova podanička uloga (time i nužnost zaštite): neka se siromasi više ne muče, te se adresati dodatno apostrofiraju kao autoritativni jamac izvršenja traženoga (nada se $u$ vašu visoku i moguću oblast da ću biti uslišan). U oba se pisma prepliću ekspozicija i dispozicija, no dok je u prvom pismu jasna izrazno-konvencionalna odijeljenost prethodnih okolnosti i aktualnoga zahtjeva: dajem na znanje (...) a sada (T1), u drugom pismu izostaju konvencionalni tekstni razlučivači: naracija se prepliće s izravnim zahtjevom onih čije pritužbe adresant posreduje: priđe... tužeći se...oli neka oltar načine kako smo se pogodili oli neka nam vrate pineze (T2). Adresant u drugome pismu u prvome licu množine, osim što izravno posreduje govor oštećenika, naglašava i svoju funkciju (autoritet) time i notu službenosti pisma (i obvezatnosti zahtijevane reakcije ili odgovora). Izravnost drugoga pisma podcrtava i eksplicitna reakcija na izostanak odgovora: i jovo pišemo drugu kjnigu niti imamo odgovora (T2). Konvencionalnu neizravnost prvoga pisma pak pojačava pozivanje na privitak (prijepis izvornoga ugovora) kao potvrdu istinitosti pravnoga čina o kojem se u ispravi svjedoči: kartu od pogodbe kako će viditi vaše pristolje u ovom zatvorenom (T1). Spomenuta reakcija na izostanak odgovora kao sastavnica drugoga pisma vidljiva je osim u strukturi isprave i u stavu o jezičnom i pismovnom kodu.

Na području šibenske biskupije u 17. i 18. stoljeću raširena je uporaba hrvatske ćirilice u vođenju matičnih knjiga pojedinih župa (o čemu su pisali Zlatović 1882, Stošić 1941, Kolendić 1915, Lisac 2014) te na kamenim natpisima (Šupuk piše o natpisima na crkvama u Mandalini, u Dubravicama kraj Skradina i na Visovcu, 1957:7-8). Franjevcima je ćirilica u 18. st. bila dominantno pismo za pisanje na hrvatskom, a njena se uporaba održala i u 19. st. (usp. Zlatović 1882). Znatno je manje bilješki o uporabi ćirilice u Šibeniku u svjetovnim i administrativnim svrhama. Pošiljatelj proučavanih pisama pokazuje svijest o ćiriličnome pismu kao mogu-

\footnotetext{
${ }^{14}$ O strukturama isprava prema Stipišić 1972.
} 
će nečitljivu šibenskim vlastima pa na različite načine osigurava recepciju. Prvo pismo pohranjeno je zajedno s latiničnim prijepisom, uz prijepis izvornoga ugovora o gradnji na talijanskom kao drugi dodatak. Latinični prijepis također ima potpis kneza Matija kao adresanta. Latinični prijepis doslovno prati ćirilični predložak: sitne razlike rezultat su prepisivačevih omaški: izostavljeno ti iz 2. retka (u ćiriličnom tekstu napisano izrazito nečitko pa je vjerojatno prepisivaču bilo nerazumljivo), izostavljeno sin iz 4. retka, zamijenjeno jedno prijedložno $s$ sa $z$ iz 7. retka, ispravljen jedan primjer sa $h$ iz 14. retka. Posebnost latiničnoga prijepisa jest interferencija pisama pa se /ć/ češće bilježi ch, no u tri je primjera zabilježeno hrvatskim ćiriličnim »đervom «: će, nećie, cineć [čineć]. Uz drugo pismo nema hrvatskoga latiničnoga prijepisa, ali je priložen prijevod na talijanski, također s potpisanim knezom Matijem kao adresantom: kako je prvo pismo ostalo bez odgovora, pošiljatelj je, osim što drugo pismo strukturira izravnije, očito smatrao da u popratnoj dokumentaciji treba promijeniti (učiniti razumljivim) i jezik pisma.

Proučavane isprave $u$ nastavku donosim u latiničnoj transliteraciji (s interpunkcijom i pravopisom kakvi su u izvorniku) uz analizu paleografskih i jezičnih osobitosti, koje posvjedočuju morfološke i ortografske osobitosti hrvatske ćirilice te stanje u ondašnjim poljičkim govorima. Posebno su izdvojena izrazna obilježja kojima se očituje promišljanje recepcije pisama. 
Gordana Čupković: Poljičko-šibenske isprave iz 1801. FILOLOGIJA 67(2016), 9-23

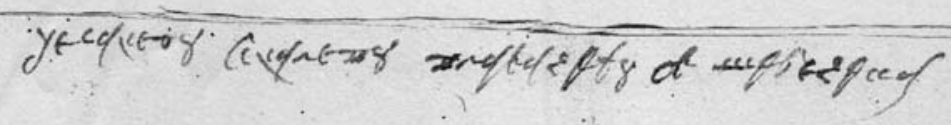

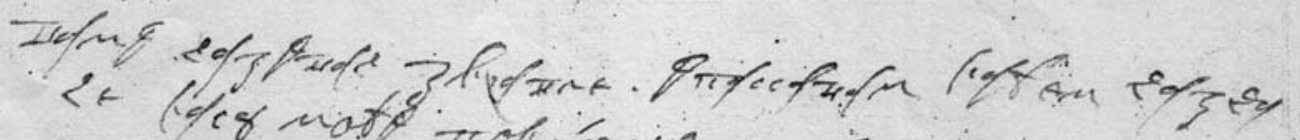

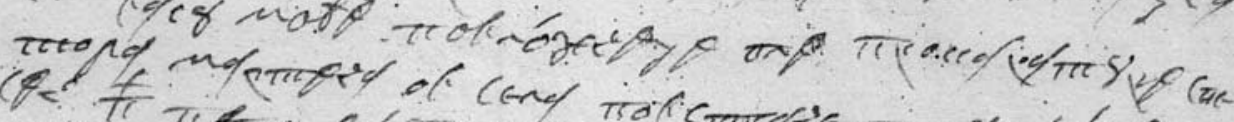

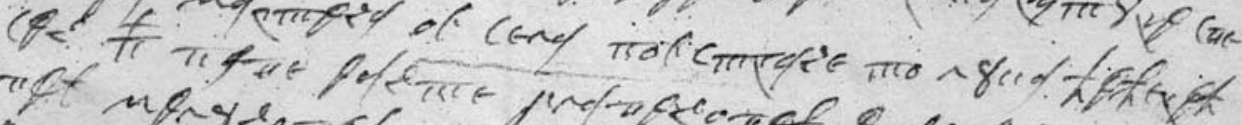

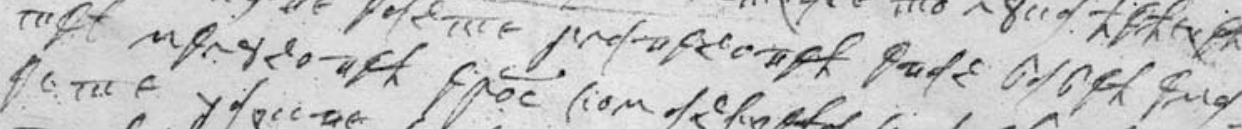

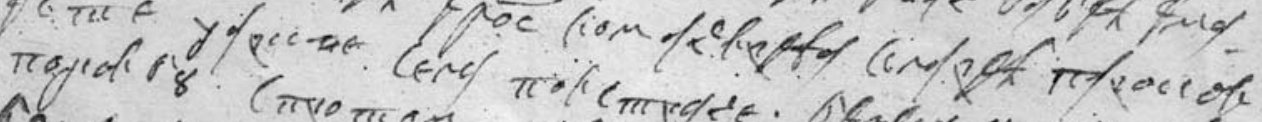

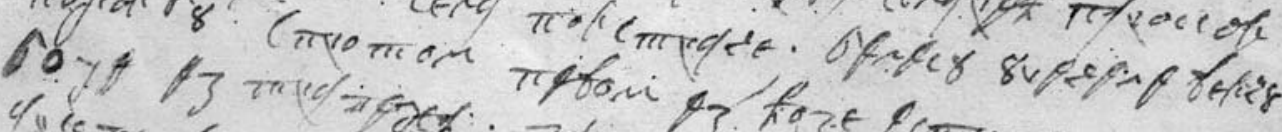

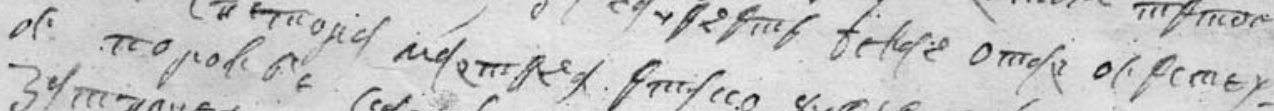

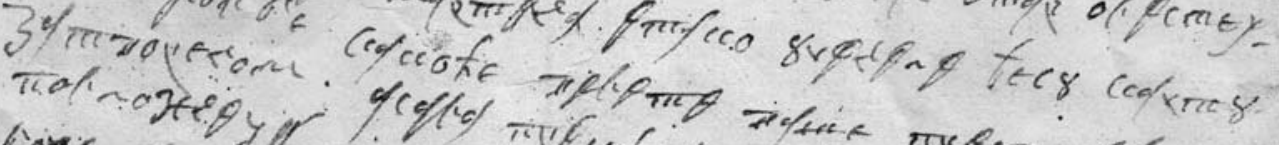

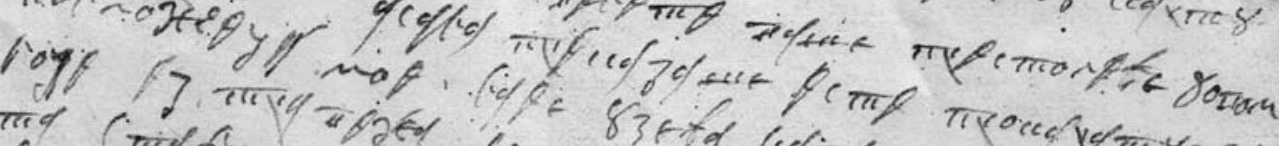

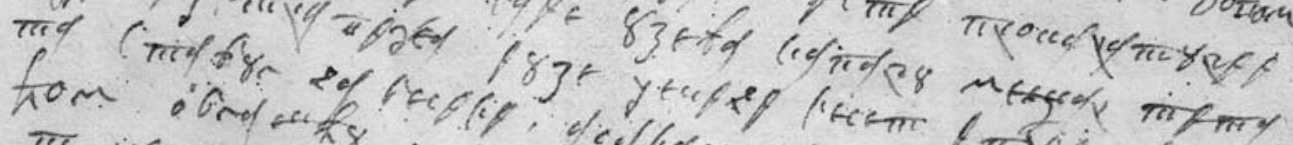

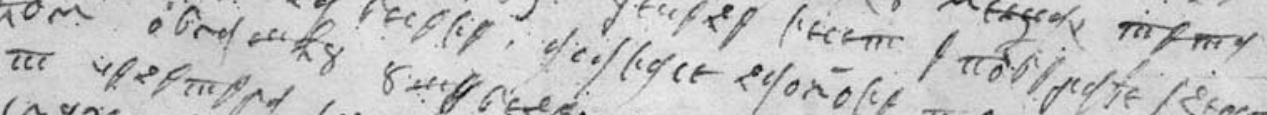

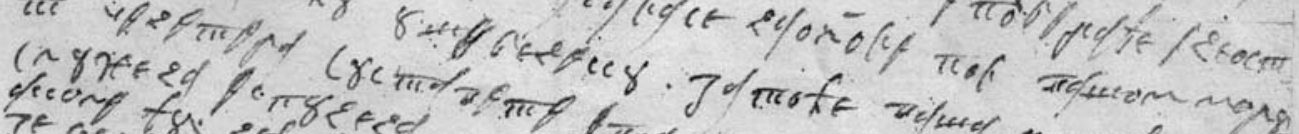

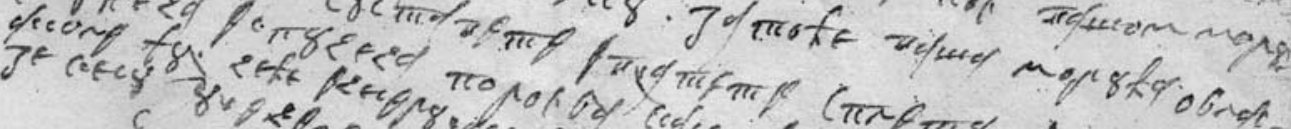

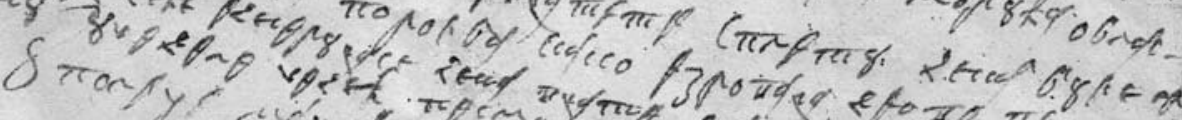

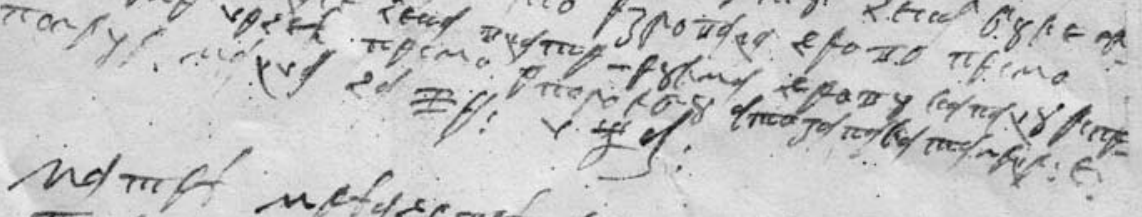

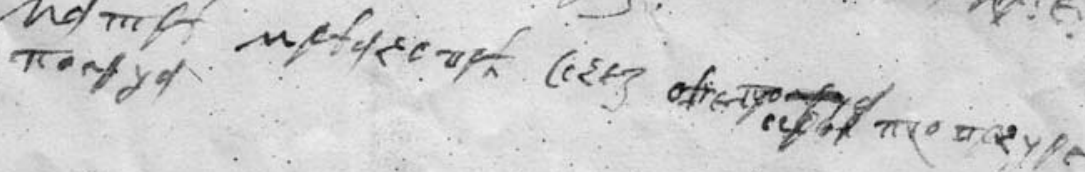

Tekst I. (Državni arhiv u Šibeniku, R 471-1801) 


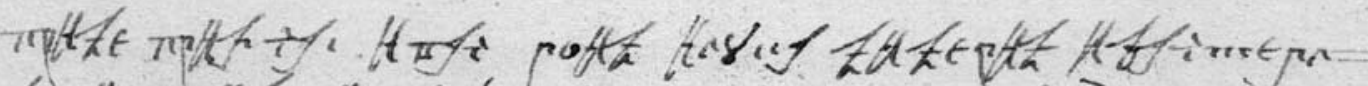

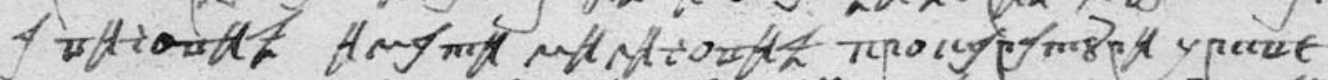

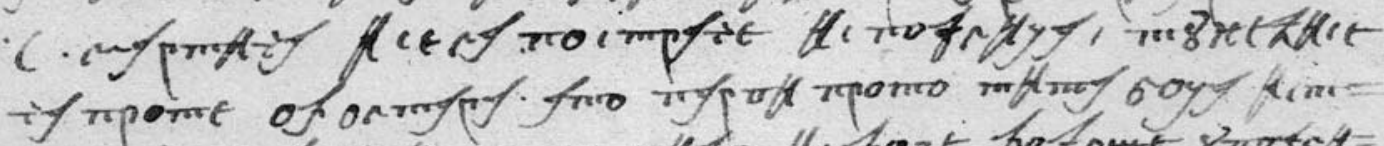

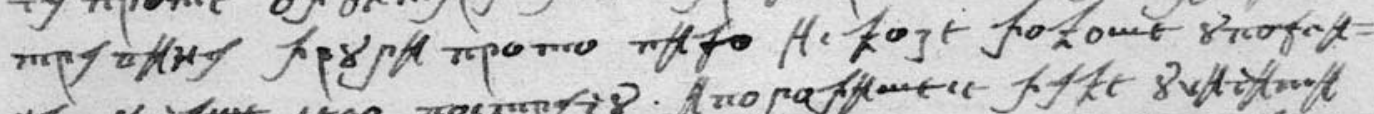

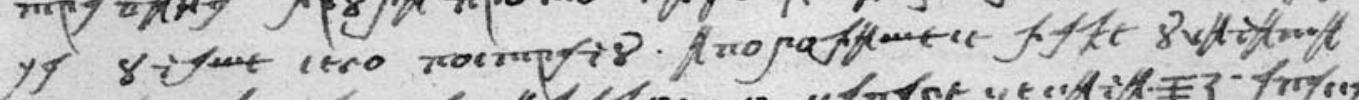

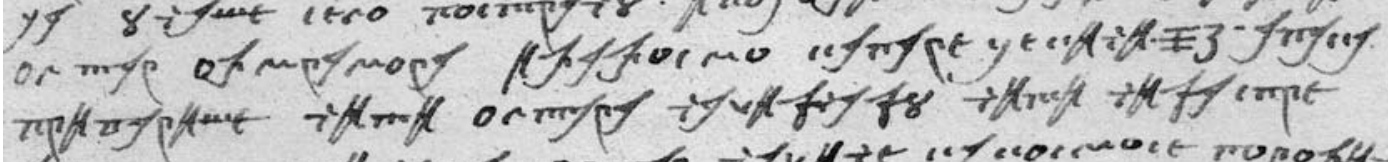

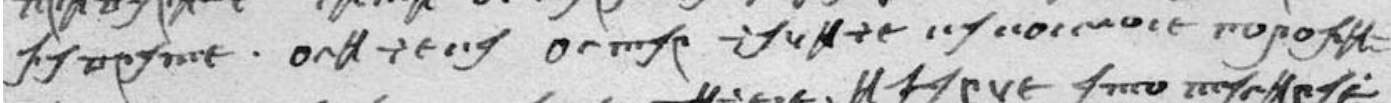

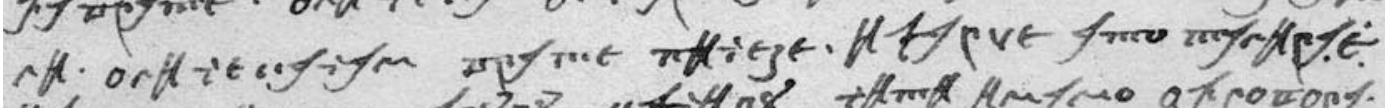

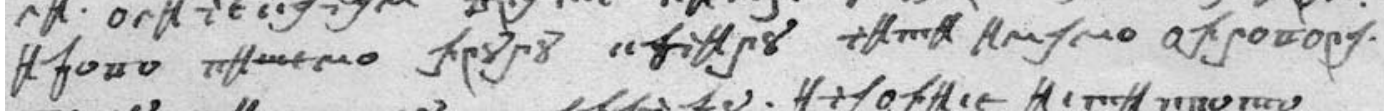

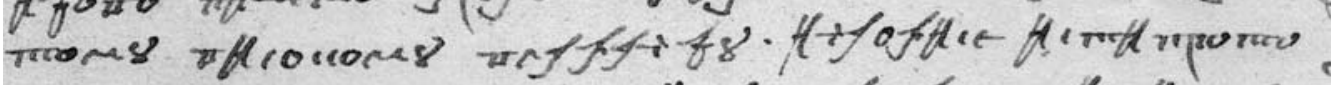

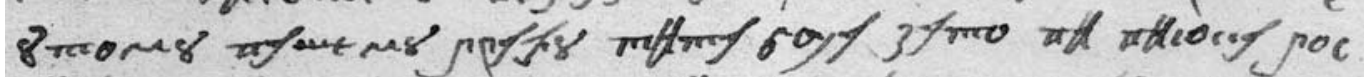

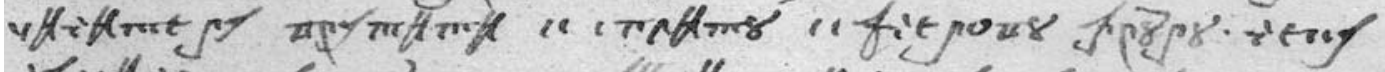

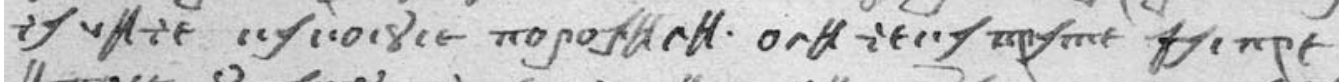

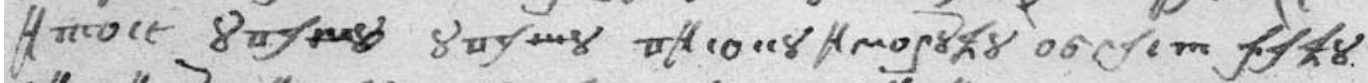

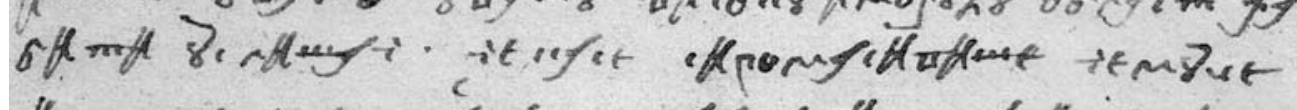

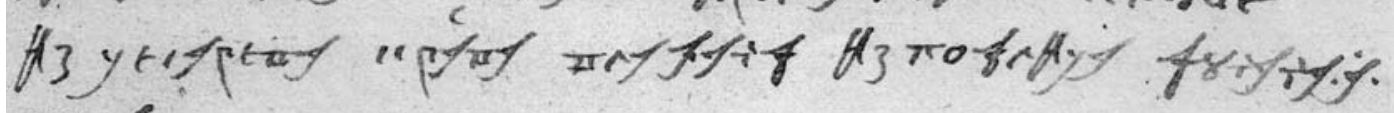
vyt.

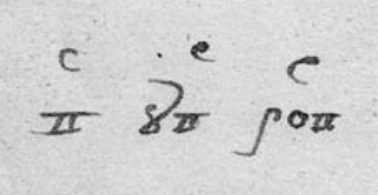

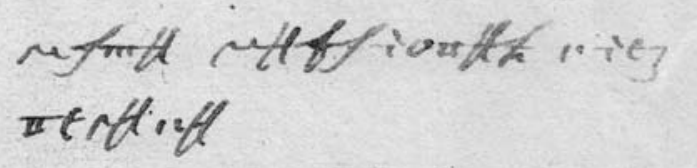

Tekst II. (Državni arhiv u Šibeniku, R 978-1801) 


\section{Tekstovi}

\section{Tekst I. (DAŠI, R 471-1801)}

Cesarsou Kralevu vladaniju od šibenika

${ }^{1}$ Vami nazivan zdravle. I paka vam dajem na zna ${ }^{2}$ ne da su moji podložnici ti prokaraturi svel ${ }^{3}$ toga martina od sela podstrane to luka ćićerić $\left.\right|^{4}$ sin p+ (pokojnoga) pave i ante glavinović ivan babić i mal ${ }^{5}$ tij milunović i gos(podin) kom. andrija klarić parok od I ${ }^{6}$ iste carkve sela podstrane. bili su učinili jednu | ${ }^{7}$ pogodbu s protom pijom iz ćoze ${ }^{15}$ is protom titom $1{ }^{8}$ boci $^{16}$ iz traviža. za načiniti jedan otar od iste c $\mid{ }^{9}$ arkve Svetoga martina i tako učinili jesu kartu। ${ }^{10}$ od pogodbe kako će viditi vaše pristolije u ovom | ${ }^{11}$ zatvorenom. a sada prikazaše isti prokaraturi i | ${ }^{12}$ podložnici moi da ie uzeja kaparu meštar tita | ${ }^{13}$ boci iz traviža i uze cekini deset i pobiga je i ne ost $\left.\right|^{14}$ ta stabul na besidi. a sada se naohodi pod vašom mogu| ${ }^{15}$ ćom oblašću u šibeniku. zato će vaša moguća oblas $\left.\right|^{16}$ t činiti ga sustaviti i vratiti Splitu neka bude ob ${ }^{17}$ služena ispunena pogodba kako izgovara niovo pismo ${ }^{18}$ ako li jur neće i ne sigura se neka vrati [m] udma niovu kaparu i spi ${ }^{19}$ ze ke su učinili čineć pismo i pogodbu a to zapada taliri .e. I ${ }^{20}$ U polici marča na .ei. .čšta. | ${ }^{21}$ matij mijanović knez od (?) polica | ${ }^{22}$ polica ki od provincie

\section{Tekst II. (DAŠI, R 978-1801)}

ce(sare)vu kra(le)v(u) vla(daniju) od šibenika

${ }^{1}$ priće prid nas ivan roić i luka ćićerić i jante gl| ${ }^{2}$ avinović i mati milinović prokaraturi crkve I ${ }^{3} S\left(\right.$ vetoga) martina i(s) sela postrane is pojlica. tužeći se I ${ }^{4}$ a prote od oltara a to parvi proto tita boca ${ }^{17}$ is $t^{5}$ traviža (!) drugi proto pijo is ćoze doćoše u pojli $\mid{ }^{6}$ ca u naše selo postranu i pogodiše se da će učiniti | ${ }^{7}$ oltar od mramora i dadosmo kapare cekini. ̈z. a paka I 8 privariše niti oltara načijnaju niti ni jaspre | ${ }^{9}$ da vrate. oli neka oltar načine kako smo se pogodi| ${ }^{10}$ li oli neka nam vrate pineze. $i$ darče (?) a to talira .e. I 11i jovo pišemo drugu kjnigu niti imamo odgovora. I ${ }^{12}$ tomu visokomu vladanju. i naodi se isti proto I ${ }^{13}$ u tomu vašemu gradu tita boca zato vi visoka gos(podo) I ${ }^{13}$ činite ga vratiti $k$ splitu $k$ jnegovu drugu. neka | ${ }^{14}$ načine kako su se pogodili. oli neka vrate jaspre | ${ }^{15} i$ to se u vašu [prekriženo šu] u vašu visoku i moguću oblast da ću | ${ }^{16}$ biti uslišan. neka se siromasi više ne muče | ${ }^{17}$ iz cesareva kra(le)va vladanj iz pojlica juna na .a. | ${ }^{18}$.čšsta. | ${ }^{19}$ v. uv. gov. | ${ }^{20}$ matj (!) mijanović knez | ${ }^{21}$ veliki | |

\footnotetext{
15 Tal. Chiozza.

16 Tal. Borzi i Bozzi.

17 Tal. Bozza.
} 


\section{Paleografija, slovopis i grafija}

Dva su teksta pisali različiti pisari što je vidljivo po rukopisu kao i u pojedinim grafijskim, znatno rjeđe i jezičnim osobinama. Prvi je rukopis teže čitljiv prvenstveno zbog redaka koji nisu linirani pa su ukošeni prema dolje. U drugom su tekstu redci simetrično raspoređeni, slova su čitljivija i pažljivije ispisana. Dva se pisara istaknuto razlikuju s obzirom na grafomorfologiju. Kod pisara prvoga teksta dijelovi slova općenito su zaobljeniji dok su kod pisara drugoga teksta slova znatnije pojednostavnjena, kurzivno vještije izvedena pa umjesto oblih dijelova dominiraju linije i otvorenost oblika. Zaobljenost i zatvorenost dijelova slova kod prvoga pisara posebno je vidljiva pri pisanju slova: $i, d, n, a, c$.

U oba teksta identično se bilježe fonemi /ć/ i /đ/, specifičnim hrvatskim ćiriličnim grafemom đerv, preuzetim iz glagoljice; u svim je primjerima transliterirano sa ć. Slovopisne razlike među pisarima posebno su vidljive u bilježenju palatala /ḷ/ i /ń/. Prvi pisar bilježi samo $l$ i $n$, kako je i u glagoljici, ali i u raznim tipovima hrvatske ćirilice: zdravle, polici, polica; znane, ispunena, niovu. Drugi pisar palatalnost označuje grafemom $j$ u prepoziciji: $j l, j n$, što je također osobitost različitih mjesta dalmatinske ćirilice ${ }^{18}$ : pojlica; načijnaju, kjnigu, jnegovu. Slijed $n+j$ drugi pisar bilježi sa $n j$ : vladanju, vladanj. Kod prvog pisara neujednačeno je pisanje fonema /j/: $j$ (moji, matij, je, pijom) i po staroslavenskome obrascu: $i(m o i, i e)$. Drugi pisar redovito bilježi j: jante, matij, pijo, jaspre, jovo; tek u jednom primjeru antroponima dolazi: mati iz kojeg nije jasno je li riječ o bilježenju /j/ grafemom $i$ ili je pak vjerojatnije riječ o glasovnoj pojavi ispuštanja završnoga $j$. Pisarsko je i bilježenje popratnoga vokala uz slogotvorno $r$ : carkve (T1), parvi (T2) ${ }^{19}$. Drugi pisar u jednom primjeru koristi kraćenje na granici riječi kakvo je učestalo i u glagoljskom pisanju, tako da se jedan od identičnih grafema na granici riječi izostavlja, no vjerojatnije je riječ o pismovnom posredovanju glasovne pojave srastanja naglasnice i proklitike na koju je prešao naglasak: is (s) sela. Oba pisara bilježe brojeve slovima i to po glagoljičnome sustavu; broj 1000 bilježi se grafemom $\check{c}$, a 800 grafemom šta ${ }^{20}$.

${ }^{18}$ Kao odmak od Berčićeve podjele hrvatske ćirilice na podtipove (dubrovački, bosanski i dalmatinski) s obzirom na bilježenje pojedinih fonema, među ostalim i s obzirom na bilježenje palatalnosti, Zelić-Bućan ističe kako rasprostranjenost pojedinih rješenja počesto nije teritorijalno zadana pa se tako različiti načini označivanja palatalnosti »isprepleću [...] vremenski i teritorijalno na čitavu području upotrebe bosančice u Dalmaciji« (Zelić-Bućan 2000:33).

${ }^{19}$ Ta je pisarska konvencija obilježje pravnih tekstova još od srednjega vijeka (usp. Kuzmić 2009).

${ }^{20} \mathrm{U}$ ćirilici se grafemom $\check{c}$ bilježi broj 90 a grafem šta nema brojevnu vrijednost. 


\section{Jezik}

Zapadni štokavski ${ }^{21}$ kao prevladavajući idiom pošiljatelja pisama posvjedočuju: ikavski refleks jata, pojedini arhaizmi, adrijatizmi kao i pojedine štokavske inovacije. Ikavizam $\mathrm{u}$ oba pisma zastupljen je $\mathrm{u}$ osobnom imenu (matij); zastupljen je i u općem leksiku, u osnovama: viditi, pobiga, besidi (T1), pineze (T2); u prefiksu: privariše (T2). Štokavski fonem /d/ zabilježen je u prefigiranim oblicima glagola iti, kao rezultat jotacije: priće, doćoše (T2). Provodi se novo jotovanje i fonema /t/: oblašću (T1). Arhaizmima pripada navezak s rotacizmom: jur (T1), te stegnuti oblik odnosne zamjenice $k e, k i$ (T1). Arhaizam je i očuvana skupina $n+j$ : vladanju, vladanj (T2), koja se dodatno produljuje: vladaniju (T1); do dodatnoga produljivanja dolazi i u skupini $l+j$ : pristolije (T1).

Od adrijatizama rjeđe dolazi do zamjene dočetnoga $m$ sa $-n$ : nazivan (T1); u većem je broju primjera - $m$ očuvano: dajem (T1), protom pijom (T1), ovom zatvorenom (T1); te sekundarno protetsko $j$ : jovo, jante (T2). Dolazi i uobičajena zamjena vokala: oli (T2) te vokalski navezak: paka (T2). Depalatalizacija je vidljiva u primjeru: kralevu (T1).

Štokavska je inovacija nepostojanje fonema /h/; na njegovu mjestu dolazi $j$, kao u prezimenu: mijanović (T1, T2), ili ništa: niovo, niovu (T1), naodi (T2). Grafem $h$ na mjestu fonema $/ \mathrm{h} /$ zabilježen je u jednom primjeru iz T1: naohodi $\mathrm{i}$ to s nadrednom crticom koja jamačno signalizira da je riječ samo o grafijskom rješenju, ne i o izgovoru; u latiničnom prijepisu to je »ispravljeno« pa dolazi: naodi. Štokavska izgovorna inovacija jest i dodatno zatvaranje vokala $o$ u susjedstvu nazala: $u d m a(\mathrm{~T} 1)$.

U T1 prijedlog je iz dok je u T2 taj prijedlog u obliku is, što može biti samo grafijsko obilježje. Zamjenički dativni oblik izjednačen je s oblikom instrumentala: vami (T1), uz obično dativno: vam (T1); živ je aorist: priće (T2), doćoše...dadosmo (T2). U kombinaciji s perfektom koristi se i pluskvamperfekt: bili su učinili (T1). Glagoli u 3. pl. prezenta imaju -e: muče se (T2); neka nam vrate (T2). Infinitiv redovito završava na -ti: učiniti (T1, T2), viditi (T1), činiti (T1), vratiti (T2)... Particip prezenta zabilježen je dvojako: čineć (T1), tužeći se (T2).

Broj 800 u ćirilici se bilježi grafemom ot koji je odraz grčkoga utjecaja na pismovnoj i fonološkoj ravni.

${ }^{21}$ Zapadni dijalekt novoštokavski je ikavski, obilježuje ga šćakavizam (uz štakavizam), primjeri refleksa $j$ od * $d^{\prime}$ te čuvanje akuta u pojedinim primjerima koji posvjedočuju stari, troakcenatski sustav. Tim je izoglosama povezan s čakavskim i kajkavskim dijalektima, kao i s drugim zapadnoštokavskim, slavonskim dijalektom. U znatnijoj mjeri povezan je s južnočakavskim govorima. Na jugu se zapadnim dijalektom govori »od Opuzena i Metkovića prema sjeverozapadu sve do Omiša« (Lisac 2003:50). 
U prvom pismu imenice muškoga roda uz brojeve dolaze s nastavkom množine: cekini deset (T1), taliri .e. (T1), dok u drugom pismu uz množinski nastavak dolazi i nastavak dvojine: cekini.ïz. (T2), talira .e. (T2) ${ }^{22}$.

Među sintaktičkim osobitostima izdvaja se uporaba genitivnih konstrukcija. Genitiv dijelni zabilježen je u primjerima: dadosmo kapare (T2), vrate jaspre $(\mathrm{T} 2)^{23}$. Slavenski genitiv dolazi u niječnoj konstrukciji s udvostručenim sastavnim veznikom (niti-niti): niti oltara načijnaju niti ni jaspre da vrate (T2), ta je rečenica smisaono disjunktivna jer njena potvrdna inačica logički ne podrazumijeva sastavnost, istinitost jedne surečenice isključuje istinitost druge. Niječna čestica $n i$, kojom se izdvaja pojedinačni primjerak iz zbirne imenice (ni jaspre), u kontaktnom položaju s veznikom niti $\mathrm{u}$ navedenom primjeru ima dominantnu funkciju pojačajne čestice. Konstrukcija s niti i slavenskim genitivom može doći i bez drugoga člana: niti imamo odgovora (T2). Konstrukcijama koje odražavaju romanski utjecaj: prijedložni izraz $z a+$ infinitiv za iskazivanje namjere: $z a$ načiniti (T1); frazeološki kalk čini + infinitiv: činiti ga vratiti (T2), činiti ga sustaviti (T1), može se pridružiti i prijedložni objasnidbeni genitiv: karta od pogodbe (T1), umjesto besprijedložnoga genitiva, kao i određivanje brojem u svojstvu pridjeva-člana: jednu pogodbu (T1). Nalog usmjeren adresatima iskazan je neizravno, futurom, kao moguća pogodba: zato će vaša moguća oblast činiti ga sustaviti i vratiti (T1), dok je nalog usmjeren na objekt pritužbe iskazan izravnom pogodbom i imperativom: ako li jur neće i ne sigura se neka vrati mi udma (T1). U drugom pismu u oba su slučaja imperativi: činite ga vratiti... neka načine...oli neka vrate jaspre (T2). Mjesto koje je cilj kretanja iskazano je dativom pri čemu dominira koncept usmjerenosti i poosobljavanja: vratiti Splitu (T1); u tom primjeru mjesto podrazumijeva administrativnu jedinicu u okviru koje je ugovor potpisan time i poosobljenu jedinicu vlasti. $U$ drugom je pismu prijedložna sintagma: vratiti k Splitu (T2). Glagol privariše dolazi kao neprelazan: a paka privariše (T2). U rečenici s više subjekata u nabrajanu glagol je određen prvim subjektom pa dolazi jednina: priće prid nas ivan roić i luka ćićerić $i$.... (T2). A pozicija u distantnom položaju, kao naknadno dodana eksplikacija, dolazi u primjeru subjekta: $i$ naodi se isti proto

\footnotetext{
${ }^{22}$ Zima ističe kako je plural tipičniji u čakavštini, a dual u štokavštini, no navodi i rjeđe primjere i iz starih dubrovačkih pisaca u kojima je također plural: satiri četiri, tri sire (Zima 1887:175).

${ }^{23}$ Obilježje je zapadnoga dijalekta općenita sklonost genitivnim konstrukcijama pa Lisac kao karakteristične navodi primjere: nije on rata ni upamtijo, pitaj zato ljudi $i$ žena, naroda pitaju (Lisac 2003:58).
} 
u tomu vašemu gradu tita boca (T2).

Frazeološki izrazi odnose se na konvenciju korespondencije: dajem na znanje (T1) te na govorne izreke: ne osta stabul na besidi (T1, 'nije održao riječ'), neće i ne sigura se (T1). Apstraktni pojmovi za spoznajne procese (znanja i govorenja) konceptualiziraju se kao kontaktne površine (prijedlogom $n a)$. Frazeološko je i zahtijevanje u imperativnoj disjunktivnoj formi »iliili«: oli neka oltar načine kako smo se pogodili oli neka nam vrate pineze (T2).

Sloj romanizama osobito je izražen u leksiku: marča (T1), meštar (T1), spize (T1; 'troškovi'), prokaraturi (T1; 'namjesnici'), karta (T1; 'dokument'24). Kao opće oznake za novac koriste se grecizam i turcizam jaspra ${ }^{25}$ te slavensko pinezi ${ }^{26}$ (T2), u oba pisma koristi se i opći administratvni naziv kapara. Kao pravni termin materijalne daće navodi se i darče. Posebni oblik leksema 'stabil(an)': stabul (T1) 'nepokretan' u ARj zabilježen je samo s potvrdom iz Poljičkog statuta (ARj XVI:332). Romanizam i grecizam proto (T1, T2) dolazi u značenju kakvo je zabilježeno u dubrovačkim tekstovima: 'poglavica nad radnicima u kakvoj radionici' (ARj XII:458).

Izdvojene jezične osobine podudarne su jeziku drugih isprava kojima je adresant knez Matij. Isprava iz Sitna (1802.): Presuda o spornoj zemlji između Roguljića i crkve Svetoga Martina (Mišerda 2003:457) podudarna je jezično i stilski pa u njoj uz gotovo redovito pisarsko ar (potvardi, Isukarsto$v a$, carkve) te govorno nepostojanje fonema $h$ (njiovi) dolazi i konstrukcija s niti: niti zemlju prigledaše. U drugoj ispravi iz Sitna (1802.) dolaze primjeri s protetskim $j$ i rotacizmom: jima, jikor, nikor (Mišerda 2003:459); u ispravi iz Donjeg Dolca (1802.) dolaze primjeri: ka, ke, izkupijo, niova (2003:462); u trećoj ispravi iz Sitna (1802.) bilježi se: koja kodir, potvarđena (2003:462).

\section{Jezik, struktura i recepcija isprava}

U radu objavljene poljičke isprave pohranjene u Državnom arhivu u Šibeniku, kao vrijedan segment korpusa hrvatskih ćiriličnih tekstova pridonose osvjetljivanju poljičko-šibenskih veza te posvjedočuju očuvanje određenih grafomorfoloških, grafijskih i jezičnih obilježja hrvatske ćirilične pismenosti i u 19. st.; uz to se u njima izdvajaju i pojedine specifičnosti vezane uz promišljanje recepcije.

${ }^{24} \mathrm{U}$ ARj (IV: 871) ističe se kako je lat. charta posuđeno preko tal. carta ili njem. karte te da se u značenju 'list na kojemu što piše' list odnosi i na 'dokument, spomenik itd'.

${ }^{25}$ ARj bilježi jaspra od 16. st. (od tur. aspre) u značenjima: 'srebrni novac', 'bilo koji novac', 'novci' (IV:483).

${ }^{26}$ Leksem pinez (od stsl. pênedzb) zabilježen je u tekstovima od 15. st. u svim refleksima jata, i kao penez, pjenez (usp. pjenez u ARj IX: 913). 
Dok paleografija i grafija jasno pokazuju dva pisara pa i dva grafijska tipa, jezični sloj dvaju pisama znatno je ujednačeniji i posve je izvjesno da odražava jezik adresanta pisama. Manje razlike u jeziku odnose se na pojedinosti (dočetno $i$ u participu prezenta) koje mogu biti i grafijske naravi (oblici prijedloga $i z$ ). Razlika u sročnosti imenica muškoga roda s brojem može odražavati i organsku dvojakost proizišlu iz supostojanja staroga i novoga oblika, koja je pojava svojom genezom manje rezultanta dodira narječja, a više odraz posjedovanja zajedničkih izoglosa. Leksičke razlike pak mogu biti stilske naravi: u drugome se pismu koriste govorni nazivi za novac, jaspra i pinezi, uz ustaljeni administrativni opći termin kapa$r a$ koji se koristi u oba pisma. Te su razlike u skladu s time što je drugo pismo strukturirano kao izravnije zahtijevanje, a što je na planu izraza vidljivo i uporabom imperativa i prema adresatima, ne samo prema objektu pritužbe.

Općenito je u oba pisma, uz stare izoglose zapadne štokavštine te izoglose koje zapadnu štokavštinu povezuju s jugoistočnom čakavštinom, posebnost i sloj adrijatizama i romanizama, koji su učestali i u glagoljskim rukopisima čitavog ranog novovjekovlja. Grafomorfološka, ortografska i jezična slika proučavanih isprava jedinstvenim zbirom specifičnosti potvrđuje već mnogo puta isticanu višestruku prožetost glagoljične i ćirilične pismenosti na istočnoj obali Jadrana.

Individualna specifičnost proučavanih isprava proistječe iz višestrukog intertekstualnoga suodnosa pisama i njihovih varijanti; taj je odnos: kronološki (ranije i kasnije ćirilično pismo), pismovni (prvo pismo na hrvatskom jeziku ćirilicom i prijepis pisma latinicom) i jezični (drugo ćirilično pismo na hrvatskom i prijevod pisma na talijanski). Stav adresanta prema adresatima, eksplicitno vidljiv u pojedinim ranije istaknutim jezičnim izrazima te u načinu strukturiranja isprave (konvencionalnu molbu u drugom pismu zamjenjuje izravna reakcija na izostanak odgovora), učitava se i početnim promišljanjem recepcije jezika i pisma (u dodatcima promjenu pismovnoga koda zamjenjuje promjena jezičnoga koda) tako i osobitim stavom prema administrativno službenome hrvatskome jeziku pisanom poljičicom kao jednoj od identitetskih posebnosti Poljičke Republike, tim značajnijoj u završnom dobu njenoga postojanja kad stalna nastojanja za održavanjem starih povlastica zadobivaju sve nepovoljnije ishode. 


\section{Literatura}

ARj: Rječnik hrvatskoga ili srpskoga jezika, I-XXIII. 1880-1976. Zagreb: JAZU.

Brković, Milko. 2005. Zadarsko-poljičke isprave iz XVIII. st. Radovi Zavoda za povijesne znanosti HAZU u Zadru 47: 247-289.

Kolendić, Petar. 1915. Fra Pavao Posilović i njegovo »Naslađenje«. Rad JAZU 206: 168-217. http://dizbi.hazu.hr/?object=dlEid=8731 (21.12.2016)

Kuzmić, Boris. 2009. Jezik hrvatskih srednjovjekovnih pravnih spomenika. Povijest hrvatskoga jezika. 1. knjiga: srednji vijek. Ur. S. Damjanović. Zagreb: Croatica: 405-451.

Lisac, Josip. 2003. Hrvatska dijalektologija 1. Zagreb: Golden marketing.

Lisac, Josip. 2014. Šibenska dionica hrvatske ćirilične baštine. Filologija 62, $131-138$.

Mišerda, Marko. 2003. Spomenici gornjih Poljica. Priko: Udruga Poljičana sveti Jure.

Pivčević, Ivan. 1921. Povijest Poljica. Split: Zemaljska štamparija u Sarajevu.

Stipišić, Jakov. 1972. Pomoćne povijesne znanosti u teoriji i praksi. Školska knjiga.

Stošić, Krsto. 1941. Sela šibenskog kotara. Šibenik.

Šupuk, Ante. 1957. Šibenski glagoljski spomenici. Zagreb.

Zelić-Bućan, Benedikta. 2000. Bosančica ili hrvatska ćirilica u srednjoj Dalmaciji. Split: Državni arhiv.

Zima, Luka. 1887. Ńekoje, većinom sintaktične razlike između čakavštine, kajkavštine $i$ štokavštine. Zagreb : JAZU. (Djela JAZU 7)

Zlatović, Stjepan. 1882. Franovci države Presvetog odkupitelja i hrvatski puk u Dalmaciji. Zagreb.

Žagar, Mateo. 2009. Hrvatska pisma u srednjem vijeku. Povijest hrvatskoga jezika. 1. knjiga: srednji vijek. Ur. S. Damjanović. Zagreb: Croatica: 107217. 


\title{
Poljica-Šibenik documents from 1801
}

\begin{abstract}
The paper brings forth two original letters that were sent by Poljica count Matija Mijanović to the authorities of the city of Šibenik in 1801. The letters are found in the State Archives in Šibenik and are written in the Croatian language and the Cyrillic alphabet. The author transcribes the texts into the Latin alphabet and compares their structural characteristics, their language and their graphic and palaeographic features. The comparative analysis results in a series of analogies and differences between the texts and the author points out to the specific discursive properties resulting from the order of sending and the sender's forethinking about the reception.

Ključne riječi: hrvatska ćirilica, poljičica, zapadni štokavski dijalekt, struktura isprave
\end{abstract}

Key words: Croatian Cyrillic alphabet, "poljičica”, western štokavian dialect, structure of the document 
